\title{
The Evolution of Theisms: The Four Technological Revolutions and the Four Theistic Revolutions
}

\author{
Dingyu Chung \\ Utica, Michigan, USA \\ Email: dy_chung@yahoo.com
}

How to cite this paper: Chung, D. (2019) The Evolution of Theisms: The Four Technological Revolutions and the Four Theistic Revolutions. Open Journal of Social Sciences, 7, 213-242. https://doi.org/10.4236/jss.2019.74018

Received: March 3, 2019

Accepted: April 16, 2019

Published: April 19, 2019

Copyright $\odot 2019$ by author(s) and Scientific Research Publishing Inc. This work is licensed under the Creative Commons Attribution International License (CC BY 4.0).

http://creativecommons.org/licenses/by/4.0/

(c) (i) Open Access

\begin{abstract}
This paper posits that in the evolution of theisms, the main function of theism is to pacify enlarged social structure derived from technological revolution. Therefore, the four technological revolutions (the Upper Paleolithic, Agricultural-Bronze, Iron, and Industrial Revolutions) produce the four enlarged social structures (linked egalitarian bands, decentralized union of hierarchical states, mega centralized empire, and global human community, respectively) whose internal conflicts to be pacified by the four theistic revolutions (the Egalitarian Band, Pluralistic State, Top-down Imperial, and Bottom-up Community Theistic Revolutions, respectively, for the egalitarian band, pluralistic state, top-down imperial, and bottom-up community theisms, respectively). This paper deals with the evolution of theisms in accordance of a biological understanding of evolution in terms of natural selection. For natural selection of the evolution of theisms through individual human innovations, theism better adapted to their environment, mainly, the technological revolution, tends to survive and propagate. In conclusion, biological evolution, the evolution of theisms, and bottom-up community theism are bottom-up processes involving bottom-up organisms' efforts.
\end{abstract}

\section{Keywords}

Theism, Evolution of Theisms, Technological Revolution, Evolution of Religions, Biological Evolution, Religions

\section{Introduction}

In the Robert Bellah's religious evolution [1], the stages of religious development follow the evolution of societies moving from the less to the more complex. However, the Bellah's religious evolution does not specify the mechanism of evolution as in biological evolution. According to Ernst Mayr [2], biological evolution is a two-step process consisting of genetic mutation to produce genetic 
variants and natural selection to select well-adapted genetic variants. For natural selection of biological evolution through individual genetic mutations, organisms better adapted to their environment tend to survive and produce more offspring. Therefore, in accordance with a biological understanding of evolution, religious evolution requires natural selection to select well-adapted religions throughout history. In "The Emergence and Evolution of Religion: By Means of Natural Selection" by Jonathan H. Turner Alexandra Maryanski, Anders Klostergaard Petersen, and Armin W. Geertz [3], in addition to Darwinian natural selection, which can explain the biology and neurology of religion, the book outlines a set of four additional types of sociocultural natural selection that can explain the origin of religion and the evolution of religion over the last 200,000 years of societal evolution. In "Religious Speciation: How Religions Evolve" by Ina Wunn and Davina Grojnowski [4], the evolution of religions is described as the adaptive modification of religions in accordance of a biological understanding of evolution.

These two books describe the evolution of religions and sociocultural environment in great details. This paper focuses on the evolution of theisms in the evolution of religions, and focuses on the technological revolution in sociocultural environment. The four technological revolutions (the Upper Paleolithic, Agricultural-Bronze, Iron, and Industrial Revolutions) significantly change the sociocultural environments. The significant changes in the sociocultural environments by the technological revolutions produce the four theistic revolutions (the Egalitarian Band, Pluralistic State, Top-down Imperial, and Bottom-up Community Theistic Revolutions). Therefore, in this paper, the three main objects are the evolution of theisms, the four technological revolutions, and the four theistic revolutions.

This paper deals with the evolution of theisms in accordance of a biological understanding of evolution. This paper posits that in the evolution of theisms, the main function of theism is to pacify enlarged social structure derived from technological revolution. An initial social structure with simple technology is converted into a transitional social structure with complex technology through technological revolution. Complex technology induces enlarged network for the production-marketing of complex technology, and produces technology driven enlarged social structure. The enlarged social structure as the combination of small social structures inevitably produces internal conflict from conflicting small social structures, resulting in disordered enlarged social structure. Such internal conflicted is pacified by pacifying theism derived from theistic revolution as in Equation (1).

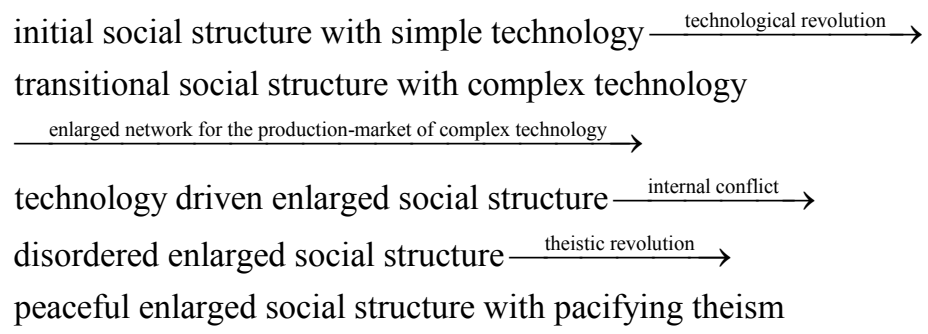


The four technological revolutions (the Upper Paleolithic, Agricultural-Bronze, Iron, and Industrial Revolutions) result in the four theistic revolutions (the Egalitarian Band, Pluralistic State, Top-down Imperial, and Bottom-up Community Theistic Revolutions) to pacify the four enlarged social structures (linked egalitarian bands, decentralized union of hierarchical states, mega centralized empire, and global human community) by pacifying their internal conflicts as in Equation (2).

egalitarian bands $\stackrel{\text { Upper Paleolithic Revolution }}{\longrightarrow}$ disordered linked egalitarian bands $\stackrel{\text { Egalitarian Band Theistic Revolution }}{\longrightarrow}$ peaceful linked egalitarian bands Agricultural-Bronze Revolution $\longrightarrow$ disordered decentralized union of hierarchical states $\stackrel{\text { Pluralistic State Theistic Revolution }}{\longrightarrow}$ peaceful decentralized union of hierarchical states

$\stackrel{\text { Iron Revolution }}{\longrightarrow}$ disordered mega centralized empire

$\stackrel{\text { Top-down Imperial Theistic Revolution }}{\longrightarrow}$ peaceful mega centralized empire

$\stackrel{\text { Industrial Revolution }}{\longrightarrow}$ disordered global human community

$\stackrel{\text { Bottom-up Community Theistic Revolution }}{\longrightarrow}$ peaceful global human community

Like the evolution of biological species based on biological genes, the evolution of theisms is based on theistic genes. For biological gens in terms of DNA, the four bases are four chemical bases: adenine (A), guanine $(G)$, cytosine $(C)$, and thymine (T). The order of the positions of these chemical bases determines the information available for building and maintaining an organism. This paper posits that the four mental bases for theistic genes are instinct (the instinctive mental protection system) [5], empiricism (observation-experience), theistic imagination (theistic theory of mind), and rationalism (rational system). The mental bases are classified in terms of priority: strong (high priority), medium (middle priority) and weak (low priority). Different theisms have different order of mental bases in terms of priority. The mechanism of evolution is natural selection. For natural selection of the evolution of biological species through individual genetic mutations, organisms better adapted to their environment tend to survive and produce more offspring. For natural selection of the evolution of theisms through individual innovations, theism better adapted to their environment, mainly, technological revolution, tend to survive and propagate as in Table 1.

Like in biological taxonomy, theistic taxonomy has kingdom, phylum, class,

Table 1. The evolution of biological species and the evolution of theisms.

\begin{tabular}{lll}
\hline & evolution of biological species & evolution of theisms \\
\hline $\begin{array}{l}\text { genetic } \\
\text { bases }\end{array}$ & $\begin{array}{l}\text { adenine }(\mathrm{A}), \text { guanine }(\mathrm{G}), \\
\text { cytosine }(\mathrm{C}), \text { and thymine }(\mathrm{T})\end{array}$ & $\begin{array}{l}\text { instinct, empiricism, theistic imagination, rationalism } \\
\text { genes }\end{array}$ \\
$\begin{array}{l}\text { different orders of genetic bases } \\
\text { in terms of positions }\end{array}$ & $\begin{array}{l}\text { different orders of genetic bases in terms of priority: } \\
\text { strong (high priority), medium (middle priority) and } \\
\text { weak (low priority) }\end{array}$ \\
$\begin{array}{l}\text { natural } \\
\text { selection }\end{array}$ & $\begin{array}{l}\text { adaption to all environments } \\
\text { through individual genetic } \\
\text { mutations }\end{array}$ & $\begin{array}{l}\text { adaption to mainly technological revolution through } \\
\text { individual innovations }\end{array}$ \\
\hline
\end{tabular}


order, family, genus, and species. For Protestantism theistic species, the kingdom is Homo, the phylum is Homo sapiens, the class is theism, the order is top-down imperial theism, and the genus is Christianity as in Table 2.

Section 2 describes the four based in the theistic genes. Section 3 explains irreligious pre-theism, egalitarian band theism, and pluralistic state theism. Section 4 describes top-down imperial theism. Section 5 explains bottom-down community theism.

\section{The Four Bases in the Theistic Genes}

In this paper, the four based in the theistic genes are instinct (the instinctive mental protection system) [5], empiricism (observation-experience), theistic imagination (theistic theory of mind), and rationalism (rational system). The mental bases are classified in terms of priority: strong (high priority), medium (middle priority) and weak (low priority). Different theistic species have different order of mental bases in terms of priority.

\subsection{The Instinct: The Mental Protection System}

The instinct is based on the mental protection system consisting of the social brain and the mental immune system to protect members of society and self, respectively, from harm [5]. The social brain consists of sociality for intragroup relations and worldview for intergroup relations. In the social brain, sociality for intragroup relations consists of collectivistic, individualistic, interdependent, and generativity relations. Collectivistic relation benefits vulnerable children against neglect by forming kinship group [5] [6] whose relations depend on commitment to a social group rather than reciprocal benefit of individuals. The origin of collectivistic sociality is the social group of caregivers and vulnerable children. Individualistic relation benefits vulnerable individuals against predation by forming alliance group [5] [7] [8] [9] whose relations depend on reciprocal benefit of individuals rather than commitment to a social group. The base of indivi

Table 2. The taxonomy of Protestantism theistic species.

\begin{tabular}{llll}
\hline taxonomy human & $\begin{array}{l}\text { Protestantism } \\
\text { theistic species }\end{array}$ & other theisms \\
\hline Kingdom & Animalia & Homo & \\
Phylum & Chordata & Homo sapiens & \\
Class & Mammalia & theism & irreligious pre-theism (extinct), atheism \\
Order & Primates & $\begin{array}{l}\text { top-down } \\
\text { imperial theism }\end{array}$ & $\begin{array}{l}\text { egalitarian band theism (extinct), pluralistic state } \\
\text { theism (extinct), bottom-up community theism (future) }\end{array}$ \\
Family & Hominidae & $\begin{array}{l}\text { personal } \\
\text { monotheism }\end{array}$ & impersonal rational theism, empirical theism \\
& & Christianity & Zoroastrianism, Judaism, Islam \\
Genus & Homo & Protestantism & Catholicism, Greek Orthodox \\
Species & Homo & & \\
\hline
\end{tabular}


dualistic sociality is extensive and complex socialization. For primates, the brain size for individualistic sociality is proportional to the group size and the complexity of socialization.

Interdependent relation benefits vulnerable specialists against handicaps by forming specialist group from specialists whose relations dependent on existential division of labor [10] [11]. The early hominins formed the interdependent specialists groups consisting of the forest group of homemaker-forager for women and children and the woodland group of explorer-forager for men in the mixed forest-woodland habitat. The handicap was the feet which were still suitable for climbing trees, and not suitable to walk long distance and run fast on the ground especially for pregnant women and small children in woodland area. Later, the division of labor became gatherer-hunter in open savanna habitat. Generativity relation benefits future generations by forming multiple-generation group whose relations depend on legacy [12] [13] [14] [15]. Unlike great apes, infertile women have long life after menopause allows multiple generations to live together. The caring of infertile women after menopause for their grandchildren and great-grandchildren is the base of legacy. The four sociality relations are collectivistic relation from kin-friends to benefit vulnerable children through commitment, individualistic relation from allies to benefit vulnerable individuals through reciprocity, interdependent relation from specialists to benefit vulnerable specialists through division of labor, and generativity relation from multiple generations to benefit vulnerable future generations through legacy as in Table 3.

In the social brain, worldview is for intergroup relations based on ingroup and outgroup. In ingroup, individuals have similar interests and outlooks, and produce the feeling of connection among them [16]. Individuals in outgroup outside the boundary of one's own group are different in interests and outlook, and produce the feeling of zero-sum competition toward outgroup. The proper behavior as morality toward ingroup is cooperation, whereas the proper behavior toward outgroup is zero-sum competition [17]. Such ingroup-outgroup boundary instinct appears even in infants at few months old [18]. Worldview relations include territorial relation for ingroup-outgroup intergroup with clear boundary between ingroup and outgroup, competitive relation for outgroup-like intergroup without clear boundary between ingroup and outgroup, and cooperative relation for ingroup-like intergroup without clear boundary between ingroup and outgroup as shown in Table 4.

Table 3. Sociality for intragroup relations.

\begin{tabular}{cccc}
\hline Intragroup Relation & Intragroup & Beneficiaries & Principle \\
\hline collectivistic & kin-friends & vulnerable children & commitment \\
individualistic & allies & vulnerable individuals & reciprocity \\
interdependent & specialists & vulnerable specialists & division of labor \\
generativity & multiple generations & vulnerable future generations & legacy \\
\hline
\end{tabular}


The immune system is a network of cells, tissues, and organs that work together to provide countermeasures against harmful invaders (pathogens). Different immune subsystems provide different countermeasures against different harmful invaders. The balanced immune system has the immune system regulators to balance the activities of the immune system. As the highly imbalanced immune system without the proper immune system regulators, the overactive immune system causes allergies and auto immune diseases as physical disorders against ubiquitous harmful and harmless detected invaders. In the same way, in the mental immune system [5], the different mental immune subsystems provide the different countermeasures against different adversities. The balanced mental immune system has the mental immune system regulators to balance the activities of the mental immune system. As the highly imbalanced mental immune system without the proper mental immune system regulators, the overactive mental immune system causes mental allergies and auto immune diseases as personality-mental disorders against ubiquitous harmful and harmless perceived adversities. The instinctive mental countermeasures in the mental immune system include comforter against hardship, hyperactivity against danger, and phobia and rationality against unfamiliarity-uncertainty. Each countermeasure has its regulator to avoid excess countermeasure. The excessive countermeasure without balancing by the regulator leads to the personality disorder. The mental immune system is instinctive, because it is mediated by neurotransmitters as in Table 5.

\subsection{Empiricism and Rationalism}

Empiricism maintains that human knowledge comes from experiences gathered through the five senses. According to empiricists, our learning is based on our observation-experience. Empiricism is an important part of the scientific method because theories and hypotheses must be observed and tested to be considered

Table 4. Worldview for intergroup relations.

\begin{tabular}{ccc}
\hline Intergroup Relation & Boundary & Intergroup \\
\hline territorial & clear & ingroup-outgroup intergroup \\
competitive & unclear & outgroup-like intergroup \\
cooperative & unclear & ingroup-like intergroup \\
\hline
\end{tabular}

Table 5. The instinctive mental immune system.

\begin{tabular}{|c|c|c|c|c|c|}
\hline countermeasure & adversity & purpose & $\begin{array}{l}\text { countermeasure } \\
\text { neurotransmitter }\end{array}$ & regulator & personality disorder \\
\hline comforter & hardship & maintain durability & endorphins & dopamine antagonist & odd-eccentric cluster \\
\hline hyperactivity & danger & maintain existence & adrenaline & serotonin agonist & dramatic-impulsive cluster \\
\hline phobia & unfamiliarity-uncertainty & maintain tradition & adrenaline-glutamate & $\begin{array}{l}\text { serotonin-GABA } \\
\text { agonist }\end{array}$ & fearful-anxious cluster \\
\hline rationality & unfamiliarity-uncertainty & maintain adaptability & adrenaline-glutamate & GABA agonist & doubtful-prying cluster \\
\hline
\end{tabular}


accurate. Initially, humans were empiricists. Like all other animals' learnings, human learning was based completely on their perception and experience. Such learning was good enough for survival and reproduction. Theism with high imagination, on the other hand, is not completely empirical. Humans did not have significant religious practices until the Upper Paleolithic Period about 40,000 year ago when theism started.

Rationalism maintains that some human knowledge is gained through a priori (prior to experience), or innate idea as distinct from sense experience. Rationalism and empiricism are the direct opposite of each other. Rationalism is the belief in innate ideas, reason, and deduction, while empiricism is the belief in sense perception, induction, and that there are no innate ideas.

\subsection{Theistic Imagination}

Theistic imagination is the imagination about supernatural which has its own mind. Theistic imagination is based on theistic theory of mind that imagines a supernatural with its own mind. Theory of mind is to recognize (imagine) that the others exist to think for themselves. Theory of mind is the evolutionary origin of religions. According to Kapogiannis and Deshpande in the functional MRI study of the brains of both self-declared religious and non-religious individuals, individuals with stronger theory of mind activity were found to be more religious [19]. Autism with the deficits in theory of mind is linked to lower belief in God [20]. Thinking about God activates brain regions associated with theory of mind [21]. Robust religion is unique to humans, because robust theory of mind is unique to humans [22]. According to Maurice Bloch [23], the first widespread human religion was derived from the imagination to produce imaginary female figurines and imaginary cave paintings to helps them to survive under existential pressure at the time of the Upper Paleolithic Revolution [24].

As shown in the previous paper [24], theory of mind was not evolved originally to accommodate religious behaviors. Theory of mind was evolved originally to accommodate interdependent division of labor between the forest specialist group (women and children) and the woodland specialist group (men) in early hominins who lived the mixed forest-woodland habitat. To complement each other's work without interfering each other's work, one specialist group had to recognize (imagine) that the other specialist group existed to think for themselves and to do different works. The result was theory of mind which is to recognize (imagine) that the others exist to think for themselves. (The forest-woodland groups became the hunter-gatherer groups for the Homo species in the savanna habitat.) Under normal condition, specialists in division of labor were real. Since theory of mind is closely related to imagination, humans under existential pressure invented imaginary specialists as imaginary agents who existed to think for themselves and to do different work in imaginary division of labor to enhance survival chance, resulting in the religious relief of stress and anxiety to enhance the survival chance of individuals [25]. Under existential 
pressure, such theistic imagination can also be the religious reinforcement of social bonds to enhance the survival chance of social group [26] [27].

\section{Irreligious Pre-Theism, Egalitarian Band Theism, and Pluralistic State Theism}

The evolution of theism starts with the initial social structure, egalitarian band with irreligious pre-theism. Subsequently, the four technological revolutions (the Upper Paleolithic, Agricultural-Bronze, Iron, and Industrial Revolutions) to enlarge social structures result in the four theistic revolutions (the Egalitarian Band, Pluralistic State, Top-down Imperial, and Bottom-up Community Theistic Revolutions) to pacify the four enlarged social structures (linked egalitarian bands, decentralized union of hierarchical states, mega centralized empire, and global human community) to produce the four theisms (egalitarian band theism, pluralistic state theism, top-down imperial theism, and bottom-up community theism). This section deals with irregular pre-theism, egalitarian band theism, and pluralistic state theism.

\subsection{Irreligious Pre-Theism: Egalitarian Band}

The evolution of theisms starts from pre-theism with the band social structure around 200,000 years ago to the beginning of the Upper Paleolithic Period about 40,000 year ago. A band society of hunter-gatherers is the simplest form of human society. A band generally consists of a small group ranging from 30 to 50 people [28]. Their power structure is egalitarian. The cooperative behaviors in a band, however, are not entirely derived from kin relation. Hill and colleagues found that the bands in their dataset are not composed mainly of close kin [29]. Bands are mainly composed of individuals either distantly related by kinship and/or marriage or unrelated altogether. In their sample of 32 societies, primary kin generally make up less than $10 \%$ of a residential band. They found that hunter-gatherers display a unique social structure where 1) either sex may disperse or remain in their natal group, 2) adult brothers and sisters often co-reside, and 3) most individuals in residential groups are genetically unrelated. Therefore, in terms of the social brain, individualistic sociality to form alliance group is much more important than collectivistic sociality to form kinship group for the human band social structure. The human social brain can manage the social group size of about 150 people (Dunbar's Number) [30], so people in a band from 30 to 50 people can deal with several bands at the same time.

The theism is irreligious pre-theism with no evidence for extensive religious practice [31]. In terms of the four mental bases, pre-theism had strong instinct, strong empiricism, weak theistic imagination, and weak rationalism. Instinct and empiricism were good enough for their survival without significant theistic imagination and rationalism. The pre-historic band society may be similar to the modern Bushman in African's Kalahari Desert as described by Marshall Sahlins' "The Original Affluent Society" [32]. It is egalitarian and peaceful. The hunt- 
er-gatherer society in small groups (about 20 - 35 people) adjusts its daily needs and desires with what is available to them. The period between childbirths is four to five years by the long prolonged lactation, so the population growth is very slow. Available food is actually fairly adequate for their modest need without population pressure. Without material accumulation, they work only for daily needs, so only the able-bodied work no more than 19 hours only a week, and $40 \%$ of people do not need to work. Without clear property lines, they welcome all visitors. They do not have to permanently stay in one social group. A great deal of evidence suggests that the prehistoric hunter-gatherer society was much less war-like than later peoples. Archaeological studies throughout the world have found hardly any evidence of warfare the prehistoric hunter-gatherer society.

\subsection{Egalitarian Band Theism: Linked Egalitarian Bands}

The Upper Paleolithic Revolution for complex tools occurred in the Upper Paleolithic Period between 10,000 and 40,000 years ago before the Agricultural Revolution. Similar to the Industrial and Agricultural Revolutions, the Upper Paleolithic Revolution during the Upper Paleolithic period represents a short time span when numerous inventions appeared and cultural changes occurred. The revolution comprised new religions, technologies, hunting techniques, human burials, and artistic work [33].

During the Upper Paleolithic Period, a number of sudden temperature drops reduced significantly the area for forest in Europe and Asia. The Neanderthal became extinct during this period. The reduction of forest reduced the food supply, usable timber, and other non-food materials. The reduction of the number of trees forced humans to look for alternatives to wood to make tools. The new tools used bone, antler, and ivory. During this time, humans also learned to apply heat to clay objects in order to harden them. Humans also made advanced tools including fish hooks, rope, oil lamps, and eyed needles.

The bands with simple tools were converted to the transitional bands with complex tools by the Upper Paleolithic Revolution for complex tools. No single or several bands within 150 people (Dunbar's Number) could make all complex tools for survive. Different bands had different specialties for tools. To obtain some useful tools, humans had to deal with total strangers in faraway places. The bands started the network for the production-marketing for complex tools. At the same time, humans also developed complex arts and decorations from shells, animal teeth, and ivory which could be very useful in trading complex tools. The network for the production-marketing resulted in technology driven linked egalitarian bands social structure with the population much more than 150 people (Dunbar's Number). The instinctive human social brain cannot manage a social group with much more than 150 people. The population in the technology driven linked egalitarian bands was too large for the instinctive human social brain. The small social group size instinct became 
the cause for the internal conflict, resulting in disordered technology driven linked egalitarian bands.

At the same time during the harsh Upper Paleolithic Period, women were under intense existential pressure to have successful fertility, while men were under intense existential to have strong vitality. The imaginary female figurines and cave paintings appeared during the period. The imaginary exaggerated and distorted female figurines were miniature sculptures of well-rounded female nudes with an overemphasis of the fleshy parts of the body (buttocks, stomach and chest). The sexual accent on the female breasts and the posterior are assumed by many to connote signs of fertility. According to Alan F. Dixson and Barnaby J. Dixson, these female figurines symbolized and brought the hope for a well-nourished and fertile community to change the fate of facing grim winters and a scarce food supply [34]. The imaginary female figurines provided the power of have successful fertility by enhancing the comforter countermeasure in the mental immune system against hardship. In the imaginary cave paints, the animals were mystic large strong animals or mystic animals with horns that symbolized maturation and strength. According to David Lewis-Williams [35], the imaginary cave paintings involved hallucinatory or trance states by drugs or repetitive rhyme. The mystic animal pictures were conceived during the trance states. These cave paintings symbolized and brought the hope for a vital and powerful community to change the fate of facing grim winters and a scarce food supply. The imaginary cave paintings provided the power to have strong vitality by enhancing the comforter countermeasure in the mental immune system against hardship. The magic in female figurines and cave paintings to bring humans hopes was driven from theistic imagination based theistic theory of mind that imagines female figurines and cave paintings had their own minds and powers to help humans to overcome such harsh conditions.

During the Upper Paleolithic Period, there was the increasingly sharing of the female figurines and the cave paintings among different bands. The enormous distribution of these female figurines implied a ritualistic exchange system with the figurines playing a central role in intergroup relations [36] to pacify the technological driven linked egalitarian bands social structure. The result was the egalitarian band theistic revolution to produce egalitarian band theism which matched egalitarian social structure of bands. Therefore, the social structure enlargement to linked egalitarian bands derived from the Upper Paleolithic Revolution for complex tools was pacified by egalitarian band theism (animism, afterlife, and shamanism) which linked egalitarian bands through theistic imagination to pacify the internal conflict due to the small social group size instinct from pre-theism as in the Equation below.

initial band social structure with simple tools $\stackrel{\text { Upper Paleolithic Revolution }}{\longrightarrow}$ transitional band social structure with complex tools enlarged infrastructure for the production-market of complex tools technology driven linked egalitarian bands social structure 
$\stackrel{\text { small social group instinct }}{\longrightarrow}$ disordered linked egalitarian bands

$\stackrel{\text { Egalitarian Band Theistic Revolution }}{\longrightarrow}$

peaceful linked egalitarian bands with egalitarian band theism

Egalitarian band theism as the shared theistic imagination became necessary and permanent part of stable linked egalitarian bands. Without religion, the Neanderthal became extinct during this period. In egalitarian band theism, the supernatural was the immanent supernatural that appeared everywhere as a part of all objects in the world. Egalitarian band theism includes animism, afterlife, and shamanism. Female figurines and cave paintings are animism. Peoples, Duda, and Marlowe found the oldest trait of religion, present in the most recent common ancestor of present-day hunter-gatherers, was animism. Belief in an afterlife emerged, followed by shamanism. Ancestor worship and high gods who are active after the Upper Paleolithic Period were absent in early hunter-gatherer, suggesting a deep history for the egalitarian nature of hunter-gatherer societies [37].

Animism, afterlife, and shamanism benefited individuals, and shared animism, afterlife, and shamanism linked egalitarian bands together. With theistic imagination through theory of mind, humans could construct an entire imaginary world where all things had magical imaginary agents that were animated and alive, and could think for themselves. This imaginary world was the base of animism that believed that all things were animated and alive [38] [39]. Shared animated objects linked egalitarian bands together. With theistic imagination through theory of mind, humans could construct an entire imaginary world where all people in the afterlife could have their own minds and powers. Shared people in the afterlife linked egalitarian bands together. Shamanism was essentially practiced by religious specialists (shamans) who specialized in using symbols, rituals, and alternate mental states to interact with the imaginary world (spirit world) to channel powers into this world [40] [41]. Shared symbols, rituals, and alternate mental states linked egalitarian bands together. In terms of the four mental bases in the theistic genes, egalitarian band theism has strong instinct, medium empiricism, medium theistic imagination, and weak rationalism.

\subsection{Pluralistic State Theism: Decentralized Union of Hierarchical States}

The Agricultural Revolution (Neolithic Revolution) started at different times at different parts of the world. The earliest started about 12,000 year ago at the Southwestern Asia. The causes of the Agricultural Revolution may have varied from region to region. The Bronze Age also started at different times at different parts of the world. The earliest started about 5500 year ago at the Southwestern Asia. The Levant saw the earliest developments of the Neolithic Revolution from around 12,000 year ago, followed by sites in the wider Fertile Crescent around 11,000 year ago. India 11,000 year ago, the Yangtze and Yellow River basins 9000 year ago, and Egypt around 6500 year ago. The Bronze Age ended about 3000 year ago when the Iron Age started. As a result, the Agricultural-Bronze Revolu- 
tion is between 12,000 and 3000 year ago.

The Agricultural Revolution through the domestication of plants and animals marked the transition in human history from small nomadic bands of hunter-gatherers to larger agricultural settlements and early civilization. The Bronze Age brought about proto-writing and other early features of urban civilization. Agricultural-bronze technology is much more complex than hunting-gathering technology, resulting in enlarged network for the production-marketing of agriculture-bronze. Such enlarged network for the production-marketing of agriculture-bronze brought about agriculture-bronze technology driven enlarged social structures such as small tribes and city states. The social structure of tribe or city state was hierarchical, while the social structure of linked egalitarian bands was egalitarian. Egalitarianism from egalitarian band theism became the cause for the internal conflict of small tribes and city states, resulting in disordered enlarged social structure. The disordered social structure was pacified by hierarchical state theism, including ancestor worship and high gods. Ancestor worship is defined as belief that the spirits of ancestors remain active in another realm where they may influence the living, and can be influenced by the living [42]. Ancestor worship allowed the hierarchical social structure to be inherited. "High gods" is defined as single, all-powerful creator deities who may be active in human affairs and supportive of human morality [43]. Ancestor worship and high gods appointed hierarchical social structures. Each tribe and city state had one dominant ancestor or high god.

A single tribe or city state was in the agricultural-bronze technology driven enlarged social structure containing many other tribes or city states. The result was the decentralized union of hierarchical states. The union could be the alliance of states or a mid-size overlord empire with a number of client states. At that time, no single state was strong enough from available technologies to centralize the powers in the union. The lack of centralized power was manifested in pluralistic state theism with polytheism which could be natural polytheism with many natural objects as deities or personal polytheism with many person-like deities. Therefore, the social structure enlargement to decentralized union of hierarchical states derived from the Agricultural-Bronze Revolution was pacified by pluralistic state theism which had hierarchical high deities to pacify the internal conflict due to egalitarianism from egalitarian band theism as in the Equation below.

linked egalitarian bands with complex stone tools $\stackrel{\text { Agricultural-Bronze Revolution }}{\longrightarrow}$ transitional social structure with agricultural-bronze technologies enlarged infrastructure for the production-market of agricultural-bronze technologies technology driven decentralized union of hierarchical states $\stackrel{\text { egalitarianism }}{\longrightarrow}$ disordered decentralized union of hierarchical states Pluralistic State Theistic Revolution $\rightarrow$ peaceful decentralized union of

hierarchical states with pluralistic state theism 
In polytheism, the chief deity was typically remote, and people worshiped their local deities. One typical example of polytheism is the polytheism in Canaan. Canaan, an ancient region between the River Jordan and the Mediterranean, located in the Levant region of present-day Lebanon, Syria, Jordan, and Israel. The chief deity was El. Israel was derived from Isra + El instead of Isra + Yahweh. During the Bronze Age and the early Iron Age, each nation had its own local deity under El [44]. Israel and Judah shared Yahweh as their national god. The various national gods were more or less equal. Because of the intermarriages and alliance among these nations, each nation had altars for the national gods of neighboring nations. According to archeological evidence [45], during this time, idols represented other religions were found commonly in Jewish homes. On the whole, Mark S. Smith shows how Israelite polytheism was a feature of Israelite religion until the seventh and sixth centuries [46]. In terms of the four mental based in the theistic genes, pluralistic state theism has medium instinct, medium empiricism, medium theistic imagination, and weak rationalism.

\section{Top-Down Imperial Theism: Mega Centralized Empire}

The Iron Age (the Iron Revolution) started between 1200 BC and 600 BC, depending on the region. Iron is tougher and lighter than bronze and was used to make much better sharp objects like spears, swords, and sharp tools than bronze. The source for iron was much more abundant than bronze. Through the Iron Revolution, the decentralized union of hierarchical states with agricultural-bronze technologies was converted to the transitional social structure with iron technology. The iron technology produced enlarged network of the production-marketing for iron technology with the world's urban population nearly doubled in the years 600 to $450 \mathrm{BC}$ [47]. The enlarged network led to the iron technology driven enlarged social structure which was mega centralized empire. The state with iron technology was strong enough with enough destructive power of iron weapons to centralize powers in the transformation of decentralized union of hierarchical states into mega centralized empire. The earliest proto-mega centralized empire is the Hittite Empire based on the advantages entailed by its high advancement on ironworking at the time [48]. The Hittite Empire was not very large, and did not last long. The earliest mega centralized empires were the neo-Assyrian empire (934 - 609 BC) and neo-Babylonian empire (612 - $539 \mathrm{BC})$. Under mega centralized empire, the chief deity to rule over local densities became useless as one single mega state could defeat all other states and their deities. Pluralistic state theism could no longer pacify mega centralized empire. Conflicting deities from pluralistic state theism became the cause for the internal conflict to produce disordered mega centralized empire. Disordered mega centralized empire led to the Imperial Theistic Revolution to produce top-down imperial theism which has top-down mega deity to simulate the all-powerful top-down mega emperor of the mega centralized empire. Therefore, the social structure enlargement to mega centralized empire derived 
from the Iron Revolution was pacified by top-down imperial theism (personal monotheism, impersonal rational theism, and empirical theism) which has top-down mega deity to pacify the internal conflict due to conflicting deities from pluralistic state theism as in the Equation below.

decentralized union of hierarchical states with agriculture-bronze

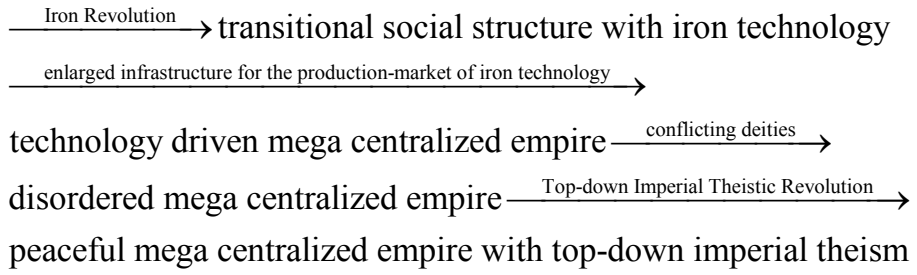

Top-down imperial theism consists of personal monotheism (Zoroastrianism, Judaism, Christianity, and Islam) based on mega personal monotheistic deity, impersonal rational theism (Hinduism, Daoism, and Greek philosophy) based on mega impersonal rational system, and empirical theism (Buddhism and Confucianism) based on mega empirical system as described in the following subsections.

\subsection{Personal Monotheism: Zoroastrianism, Judaism, Christianity, and Islam}

For personal monotheism, the simulated top-down mega emperor in mega centralized empire is the top-down mega supernatural leader. The earliest mega centralized empire with top-down imperial theism is the Persian Empire (550 $330 \mathrm{BC}$ ) with personal monotheism which is monotheistic Zoroastrianism. Zoroastrianism was found by the prophet Zoroaster traditionally dated to the $6^{\text {th }}$ century $\mathrm{BC}$ in the Iron Age after and during the time of the mega centralized neo-Assyrian and neo-Babylonian empires. Polytheism did not work well in mega centralized empire, resulting in the rise of personal monotheism. Zoroastrians believe in one God, called Ahura Mazda (meaning "Wise Lord"). He is compassionate, just, and is the creator of the universe. Zoroaster placed less emphasis on ritual worship, instead focusing on the central ethics of 'Good Words, Good Thoughts and Good Deeds'. The creator became the simulated mega benevolent emperor.

The failure of polytheism as the alliance of deities for the alliance of states led to the development of personal monotheism in Israel and Judah. In 722 BC, Israel was defeated by the mega Assyria Empire which was strong enough to defeat various states with enormously destructive army and iron weapons. Israelites witnessed the failure of polytheism with the alliance of deities for the alliance of states. No alliance could defeat the mega Assyria Empire who looked down at all local deities. To some Israelites, the only salvation was to convert the local deity of Yahweh into the mega universal deity of Yahweh who had the power over all earthly empires. The mega universal deity of Yahweh was the only answer to oppose the mega emperor of the mega Assyrian Empire [49]. The mega universal deity was monotheism. Some of the refugees who fled from Israel 
to Judah brought with them the Yahweh only monotheism to Judah, and convinced some very influential people to believe in monotheism replacing polytheism. Several kings in Judah became the strong supporters of monotheism. To the believers of monotheism, the practice of polytheism by Israelites was the reason for the defeat and suffering of Israelites as the punishment by monotheistic Yahweh. However, Yahweh, the universal deity, would not abandon Israel-Judah, and one day Israel-Judah would rise again under monotheistic Yahweh.

Judaism is very restrictive with various rules and traditions. Christianity with much less rules and traditions is basically a broaden Judaism appealing to all people, and maintains monotheism to appeal to mega centralized empires. Eventually, the mega centralized Roman Empire adopted Christianity as the state religion. Islam is another personal monotheism suitable to mega centralized empires.

Among the four mental bases for personal monotheism, the strongest base is theistic imagination with theistic theory of mind that images the universal deity with its own mind. Consequently, instinct for the instinctive mental protection system (the social brain and the mental immune system) is medium, and empiricism for observation-experience is weak. Rationalism base is medium to form a rational system for the universal deity. The 10 commandments in the Bible are as follows.

1) You shall have no other Gods before me

2) You shall not make for yourselves an idol

3) You shall not misuse the name of the LORD your God

4) Remember the Sabbath day by keeping it holy

5) Honor your father and your mother

6) You shall not murder

7) You shall not commit adultery

8) You shall not steal

9) You shall not give false testimony

10) You shall not covet

The first four commandments are derived from theistic imagination. The fifth commandment is in collectivistic sociality for kin group in the instinctive social brain. The last five commandments are in individualistic sociality for alliance group in the instinctive social brain.

In personal monotheism, God becomes heavenly parent for individual believers. In the Abrahamic religions (Judaism, Christianity, and Islam), God is assumed implicitly or explicitly as heavenly parent, while the believers are God's children. In the Abrahamic religions, the mental immune system of adult believers relies on heavenly parent as that the mental immune system of dependent children relies on parents. To dependent child, committed parents are the protector against danger, the authority against unfamiliarity-uncertainty, and the love against hardship. To the adult believers in the Abrahamic religions, heavenly parent provides the protection against danger, the authority against unfamiliarity-uncertainty, and the love against hardship. The heavenly parental protection in the form of miraculous salvation is the religious hyperactivity as 
the countermeasure against danger. For Judaism, the confirmation for the miraculous salvation is the miraculous salvation of Israelites from oppression and the deliverance into the Promised Land. For Christianity, the confirmation is the miraculous salvation through Jesus' sacrifice and resurrection. For Islam, the confirmation is the miraculous salvation of Mecca to herald the advent of the Prophet Muhammad. The Abrahamic religions celebrate the miraculous salvations every year. The heavenly paternal-like authority in power, laws, and traditions provides the phobia against moving to unfamiliar-uncertain way of life (sins). The authority is expressed as righteousness. For the Abrahamic religions, the heavenly authority (righteousness) is written in the sacred scriptures. The heavenly maternal-like love is the religious comforter as the countermeasure against hardship. For the Abrahamic religions, God is love. Whenever the believers face adversities, the believers seek relentlessly for the heavenly miraculous salvation against danger, the heavenly authority against unfamiliarity-uncertainty, and the heavenly love against hardship.

As for small children, the religious immune system in the Abrahamic religions started with the unregulated immune system without any delayed gratification. The impatient believers want the religious countermeasures at once. There are many stories about such unregulated religious countermeasures in the Abrahamic religions. For examples, in the long journey from Egypt to the Promise Land, Israelites frequently complained, and wanted immediate miraculous salvation without delay as what infants normally do. Inevitably, God taught Israelites to wait for the right time with delayed gratification. God the heavenly parent introduced the heavenly providence (wisdom) as the religious regulator to regulate the religious immune system. The heavenly providence prevents overactive religious countermeasure against ubiquitous perceived adversity as in personality-mental disorders. Believing in the heavenly providence, a believer in the heavenly miraculous salvation looks beyond prevailing danger to the coming of the divine salvation, resulting in the elimination of the overactive religious hyperactivity against ubiquitous perceived danger. Believing in the heavenly providence, a believer in the heavenly authority looks beyond prevailing unfamiliarity-uncertainty (sins) to the coming of the heavenly authority, resulting in the elimination of the overactive religious phobia against ubiquitous perceived unfamiliarity-uncertainty. Believing in the heavenly providence, a believer in the heavenly love looks beyond prevailing hardship to the coming of the heavenly love, resulting in the elimination of the overactive religious comforter against ubiquitous perceived hardship. Essentially, the Abrahamic religions follow the natural regulated immune system for children. The religious mental immune system for the Abrahamic religions is in Table 6.

\subsection{Impersonal Rational Theism: The Greek Philosophy, Hinduism, and Daoism}

During the Persian Empire in Athens, Socrates (470 - 399 BC) doubted about the polytheistic gods in Greece. His doubt (impiety) about polytheistic gods of the 
Table 6. The religious mental immune system the Abrahamic religions.

\begin{tabular}{cccc}
\hline adversity & $\begin{array}{c}\text { instinctive mental } \\
\text { countermeasure }\end{array}$ & $\begin{array}{c}\text { religious mental } \\
\text { countermeasure }\end{array}$ & $\begin{array}{c}\text { religious mental immune } \\
\text { system regulator }\end{array}$ \\
\hline hardship & comforter & divine love & divine providence \\
danger & hyperactivity & divine miraculous salvation & divine providence \\
$\begin{array}{c}\text { unfamiliarity- } \\
\text { uncertainty }\end{array}$ & phobia & divine authority & divine providence \\
\hline
\end{tabular}

state led to his execution [50] and the rise of impersonal rational theism from his disciples, such as Plato (427 - $347 \mathrm{BC}$ ), to replace polytheism. Impersonal rational theism based on mega impersonal rational system is different from personal monotheism based on mega monotheistic deity. One example of impersonal rational theism is the Plato's Form of the Good which is the ultimate rational system of knowledge and the source of the perfect types to exist from all eternity. Impersonal rational theism is impersonal and rational, while personal monotheism is personal and authoritative. The mega centralized empires after the Persian Empire with personal monotheism as Zoroastrianism is the Greek-Hellenistic Empire (331 - 146 BC) with impersonal rational theism as the Greek philosophy such as the Plato's Form of the Good. The Empire tolerated polytheism. After the Greek-Hellenistic Empire, the Roman Empire (27 BC - 476 AD) adopted the Greek philosophy, and tolerated polytheism until $313 \mathrm{AD}$. The Form of the Good allowed people to pursuit anything that was considered good, beautiful, and rational. The government followed a highly rational legal system.

Impersonal rational theism includes the Greek philosophy, Hinduism, and Daoism. In terms of the four mental bases in the theistic genes for impersonal rational theism, rationalism is strong, theistic imagination is medium, and instinct and empiricism are weak. In Hinduism, God (Brahman) is the one impersonal, ultimate, but unknowable, spiritual reality, and is the material, efficient, formal and final cause of all that exists and the highest Universal Principle, the Ultimate Reality in the universe [51]. In the Hindu impersonal rational system, the impersonal Brahman becomes personalized creator (Brahma), preserver (Vishnu), and destroyer (Shiva). They produce many incarnations and associate deities. The goal of Hindu life is to achieve Moksha (salvation from samsara as the cycle of death and rebirth) and to unite the atman (person's soul) with the Brahman. The Upanishads that started from about the $7^{\text {th }}$ century BC shows that Atman is the same reality and the same aesthetics as the Brahman.

The founder of Daoism is Laozi, who existed in the $6^{\text {th }}$ century BC but about whom little else is known. China under Shang Dynasty (1700 - 1046 BC) and Zhou Dynasty (1046 - 256 BC) was a mid-size empire with the decentralized union of hierarchical states. The periods of the last five hundred years of Zhou Dynasty were the Spring and Autumn period (771 - 476 BC) and the Warring States period (475 - $221 \mathrm{BC}$ ) when the Zhou court had little control over its constituent states that were at war with each other. During these two periods, many 
schools of philosophy emerged to offer various advices to govern the states and to replace polytheism under the Zhou Dynasty. Daoism was one of the schools.

Daoism [52] emphasizes living in harmony with the impersonal Dao (literally: "the Way") which is the rational system of everything that exists, so Daoism is impersonal rational theism. The rational system includes the yin yang dualism, the Eight Trigrams, the Four Elements, the Five Phases, and the simplification of life. The simplification of life emphasizes wu wei (action without intention), naturalness, spontaneity, and the three virtues: compassion, frugality, and humility. The utopia is a small, simple, peaceful, natural, and frugal society as in Dao Te Jing Chapter 80. "Let the people cherish their life and not pursue after fame and wealth, so that they have no intention to move to faraway places. Although there are boats and carriages, no one will ride them. Although there are weapons and armors, there is no occasion to display them. Let the people return to the ancient simple life where knotting ropes were used to record every event. People would then enjoy the simple food, simple clothing, and be contented with a simple life. And they shall live happily with the traditional customs. Neighbors of the nations overlook one another in the near distance. The barks of dogs and crowing of cocks can be heard. Yet people are so contented that they enjoy their life without ever visiting each other."

For some emperors in China, the Daoist simplification of life was the simplification of government to reduce governmental spending, taxes, rules, and military force. For some Daoists, the simplification of life also moves Daoism back to egalitarian band theism for simple prehistoric linked egalitarian band social structure. As a result, Daoism that dislikes rigid hierarchical rituals from state theism is both impersonal rational theism and egalitarian band theism.

\subsection{Empirical Theism: Buddhism and Confucianism}

Urbanization in the Iron Age transformed simple and collectivistic rural society into complex and individualistic urban society. Pluralistic state theism (polytheism $=$ paganism $=$ rural religion) based on rituals for rural society could not deal with such complex and individualistic urban society. This period is often called the "Axial Age" (800 - 200 BC) [53]. Replacing pluralistic state theism (polytheism), personal monotheism, impersonal rational theism, and empirical theism deal with complex and individualistic urban society with different methods. For personal monotheism (Zoroastrianism, Judaism, Christianity, and Islam), the believers rely on idealistic monotheistic God through idealistic devotion. For impersonal rational theism (Greek philosophy, Hinduism, and Daoism), the believers rely on the idealistic rational system through idealistic rational thinking. For empirical theism (Buddhism and Confucianism), the believers rely on the realistic instinctive mental protection system through realistic empiricism in terms of observation and experience. With empiricism (observation-experience), Buddha and Confucius learned various ways to nurture the instinctive mental protection system consisting of the social brain and the metal immune system. 
Buddha and Confucius taught their disciples such ways which are morality and social relationships for the social brain and mental exercise for the mental immune system. The practices of such methods through empiricism (observation-experience) allow citizens to have the strong instinctive mental protection system. The good citizens with the strong instinctive mental protection system build strong mega centralized empire. In terms of the four mental bases in the theistic genes, empirical theism has strong instinct and empiricism and medium theistic imagination and rationalism.

Gautama Buddha (about 563 - 483 BC), founder of Buddhism, was born in the warrior caste in one of city-states in the central Ganges basin under the social structure of decentralized union of hierarchical states with the "Second urbanization". The theism was pluralistic state theism as polytheism. The city-states were coalesced gradually. Increasing urbanization and the coalescence of states led to the rise of new ascetic movements to challenge the orthodoxy of rituals of polytheism [54]. Through observation and experience, Buddha found the middle way of moderation between the extremes of sensual indulgence and self-mortification to amend the extreme asceticism in the movements [55]. Buddha taught his disciples the middle way.

The goal of Buddhism is to overcome suffering and the cycle of death and rebirth by the attainment of Nirvana. Basically, sufferings are derived from the failure to deal with the complex and individualistic urban society, resulting in ignorance and greed. As a result, the Four Noble Truths in Buddhism shows that 1) all life is suffering, 2) the causes of suffering are ignorance and greed, 3) ignorance and greed can be eliminated, and 4) the means to this is the Eightfold Path consisting of right view, right aspiration, right speech, right action, right livelihood, right effort, right mindfulness, and right concentration. The extreme forms of the sufferings are manifested as the social disorders from the abnormal social brain and the personality/mental disorders from the abnormal mental immune system. The sufferings like the social disorders can be minimized with right view, right aspiration, right speech, right action, right livelihood, and right effort in the Eightfold Path. The sufferings like the personality/mental disorders can be minimized with right mindfulness (mindfulness meditation) and right concentration (concentration meditation) in the Eightfold Path. The emotion regulation from meditation [56] has been investigated to show the decreases in emotional interference by unpleasant stimuli and in the time to return to emotional baseline after stress. The emotional regulation relates to the strengthening of prefrontal cognitive control mechanisms. The attainment of Nirvana (literally "blown out" as in an oil lamp) is the ultimate attainment of peace of mind. Buddhism was adopted by the mega centralized Maurya Empire (322 - 185 BC) that spread Buddhism from the Maurya Empire to Sri Lanka, Central Asia, Southeast Asia, Egypt, and Hellenistic Europe. Buddhism also was spread to China, Korea, and Japan.

Confucius (551 - 479 BC) was born in effectively independent state of Lu no- 
tionally controlled by the kings of Zhou during the Spring and Autumn period (771 - 476 BC). His father, a commandant of the local Lu garrison, died when Confucius was three years old, and Confucius was raised by his mother in poverty. The states were at war with each other, and high government officers within a state were at war with each other. The politics in China was complex and individualistic. During this Hundred Schools of Thought era, many schools of philosophy offered rulers advices to govern the states. Confucius travelled to many states to offer advices, participate in government, and educate more than three thousand people.

The Four Books in Confucianism are comprised of the Great Learning, the Doctrine of the Mean, the Analects, and Mencius [57]. The first book to read is the Great Learning attributed to Confucius with nine commentary chapters by Zengzi, one of the disciples of Confucius. It is a guide for moral self-cultivation. In the Great Learning, the sequence of learning starts with empiricism as investigation. "Things being investigated, knowledge became complete. Their knowledge being complete, their thoughts were sincere. Their thoughts being sincere, their hearts were then rectified. Their hearts being rectified, their persons were cultivated. Their persons being cultivated, their families were regulated. Their families being regulated, their states were rightly governed. Their states being rightly governed, the whole kingdom was made tranquil and happy (the Great Learning 1:5).”

The second book to read is the Doctrine of the Mean attributed to Confucius' grandson Zisi. It is to demonstrate the usefulness of the middle way (mean) to maintain balance. The first chapter of the Doctrine of Mean from Confucianism describes how to maintain mental balance. "When joy, anger, sorrow and pleasure have not yet arisen, it is the state of equilibrium. When they arise to their appropriate levels, it is the state of harmony. The state of equilibrium is the great base of of all-under heaven. The state of harmony is the universal path to be pursued. When the states of equilibrium and harmony are actualized, Heaven and Earth are in their proper positions, and all things are nourished." The goal of the balance in the balanced mental immune system is to reach the state of equilibrium without arising emotion and the state of harmony with arising emotion to balance adversity-fortune. Whenever one thinks too much about adversity, think about possible fortune after adversity. Equally, whenever one thinks too much about fortune, thinks about possible adversity after fortune. Such thinking helps to nurture the normal instinctive mental system which is regulated to maintain balance.

The Great Learning is about the sequence of learning starting with investigation as empiricism. The Doctrine of Mean is about the middle way (mean) to maintain balance. In the Analects and Mencius, the good society based on the proper social behaviors of the individuals at home and in broad society is the base of the good government with the proper relationship of the government and the citizens. The Analects is a collection of Confucius' teachings and discussions with disciples. The Analects emphasize the importance of good 
governance and proper social behaviors. Mencius, Confucius' disciple, is a collection of conversations Mencius had with Confucius. Mencius emphasizes the responsibility of the emperor to practice good governance.

The proper social behaviors help to nurture the normal instinctive social brain consisting of sociality for intragroup relations (collectivistic sociality, individualistic sociality, interdependent sociality, and generativity sociality) and worldview for intergroup relations (cooperative worldview, competitive worldview, and territorial worldview). Collectivistic sociality is for kin group whose principle is commitment. In Confucian morality for kin group, parent-child relation involves care and teaching from parent and filial piety from child. Husband-wife and elder-younger siblings show respect, responsibility, and loyalty for each other. Individualistic sociality is for alliance group whose principle is reciprocity. The Confucian morality for alliance group involves ren (benevolence), yi (uprightness), xin (faithfulness), shu (reciprocity), and li (propriety). Interdependent sociality is for specialist group whose principle is division of labor. The Confucian morality for division of labor involves the specific responsibility of each specific role. Duke Jing of Qi asked Confucius about government. Confucius replied: "Let the ruler be a ruler, minister be a minister, father be a father, son be a son." (Analects 12:11) Generativity sociality is for multiple-generation group whose principle is legacy. The Confucian morality for generativity is ancestor veneration to keep the memory of many generations. For intergroup relations (worldviews), Confucianism encourages cooperative worldview. Cooperative worldview is expressed as harmony. "In practicing the rules of propriety, it is harmony that is prized." (Analects 1:12) Harmony is prized among the differences. Confucius said: "Noble persons seek harmony but not sameness. Petty persons seek sameness but not harmony." (Analects 13:23). The Confucian mental protection system is listed in Table 7.

Table 7. The confucian mental protection system.

\begin{tabular}{|c|c|c|c|}
\hline Intragroup Relation (sociality) & Intragroup & Principle & Confucian morality \\
\hline collectivistic & kin & commitment & $\begin{array}{l}\text { parent (care)-child (filial piety), husband-wife, elder- } \\
\text { younger sibling (respect, responsibility, and loyalty) }\end{array}$ \\
\hline individualistic & alliance & reciprocity & $\begin{array}{l}\text { ren (benevolence), yi (uprightness), xin (faithfulness), } \\
\text { shu (reciprocity), li (propriety) }\end{array}$ \\
\hline interdependent & specialist & division of labor & responsibility for a special role \\
\hline generativity & multiple generation & legacy & ancestor veneration \\
\hline Intragroup Relation (worldview) & Intergroup & Boundary & \\
\hline cooperative & ingroup-like intergroup & unclear & encourage cooperation \\
\hline competitive & outgroup-like intergroup & unclear & restricted competition \\
\hline territorial & ingroup-outgroup intergroup & clear & restricted territorialism \\
\hline Mental Immune System & System & Principle & \\
\hline to counter mental adversity & adversity-countermeasure-regulator & balance & the Doctrine of Mean \\
\hline
\end{tabular}


Confucius continued to maintain theism. Confucius said, "There are three things of which the superior man stands in awe. He stands in awe of the ordinances of Heaven. He stands in awe of great men. He stands in awe of the words of sages." (Analects 16:8). However, he was careful about speculative spirits. Confucius said, "Working to give the people justice and paying respect to the spirits, but keeping away from them, you can call wisdom." (Analects 6:22). The ultimate goal of Confucianism is the Great Harmony. "When the Great Principle prevails, the world is a Commonwealth in which rulers are selected according to their wisdom and ability. Mutual confidence is promoted and good neighborliness cultivated. Hence, men do not regard as parents only their own parents, nor do they treat as children only their own children. Provision is secured for the aged till death, employment for the able-bodied, and the mean of growing up for the young. Helpless widows and widowers, orphans and the lonely, as well as the sick and the disable, are well cared for. Men have their respective occupations and women their homes. They do not like to see wealth lying idle, yet they do not keep it for their own gratification. They despise indolence, yet they do not use their energies for energies for their own benefit. In this way, selfish scheming are repressed, and robbers, thieves and other lawless men no longer exist, and there is no need for people to shut their outers. This is called the Great Harmony (TA TUNG)." (The Chapter of Great Harmony (Ta Tung)) Confucianism has a broad appeal to the people who want to have good and realistic social relations, mental balance, deity, government, and the harmonious world.

During the Spring and Autumn period (771 - 476 BC) and the Warring States period (475 - $221 \mathrm{BC}$ ), the wars among the states in China produced the strong military states which expanded the territory of China greatly from a mid-size decentralized empire to a mega decentralized empire. At the same time, China transited from the Bronze Age to the Iron Age gradually. Qin state finally unified China under the Qin dynasty as the first mega centralized empire (221 - 206 BC) with legalism which relied on clear laws and strict punishments. The emperor (Qin Shi Huang) attempted to destroy all other schools of philosophy. Legalism that built the strong and well-organized Qin Empire had a narrow appeal. As a result, the Qin dynasty was disordered, and ended quickly after his death. The Han dynasty (206 BC - 220 AD) after the Qin Dynasty adopted Confucianism as the official ideology which was the pacified force to make the Han Dynasty a long and strong dynasty. Consequently, Confucianism has dominated China continuously for more than two thousand years. Korea, Japan, and Viet Nam have also adopted Confucianism.

The adoption of Christianity as the state religion by the emperor Constantine in $313 \mathrm{AD}$ led to the downfalls of the Greek philosophy and polytheism in the Roman Empire. However, Islam countries were open to the Greek philosophy which was translated into Arabic. During the Renaissance between the $14^{\text {th }}$ and $17^{\text {th }}$ centuries, the Greek philosophy was re-introduced to Christian Europe through mostly the Islam countries. The Greek philosophy as impersonal ra- 
tional theism led to the emergence of European rationalism through Descartes, Leibniz and Spinoza. Since in the Greek philosophy, Aristotle was an empiricist, the re-introduction of the Greek philosophy also led to the emergence of European empiricism through Bacon, Locke, Berkeley, and Hume. The combination of European rationalism and empiricism produced modern science. The success of early modern science brought about deism in the $17^{\text {th }}$ and $18^{\text {th }}$ centuries. As impersonal rational theism, deism accepts the existence of an impersonal creator on the basis of reason but rejects belief in a personal deity who interacts with humankind [58]. Some of the famous deists are Adam Smith, George Washington, Benjamin Franklin, Thomas Paine, Thomas Jefferson, James Madison, Napoleon Bonaparte, Abraham Lincoln, Thomas Edison, Mark Twain, and Neil Armstrong.

\section{Bottom-Up Community Theism: Global Human Community}

The Industrial Revolution contains four stages. The first industrial revolution began in Britain in the late $18^{\text {th }}$ century. It was centered on textiles, steam power, and iron. The second industrial revolution was between 1870 and 1914 after the civil war in America. It was centered on steel, railroads, petroleum, chemicals, and electricity. The third industrial revolution as the information revolution began in the 1980s with the proliferation of digital computers, digital record, personal computers, the internet, and information and communications technology. The fourth industrial revolution builds on the third industrial revolution, and combines robotics, artificial intelligence, nanotechnology, quantum computing, biotechnology, the Internet of Things (IoT), decentralized consensus, 3D printing, and autonomous vehicles [59]. The fourth industrial revolution allows highly individualized global production-marketing-information. In the Industrial Revolution, the dramatic increase in productivity lifted most people from the poverty. Intense existential environmental pressure in the agricultural society has been greatly reduced in the industrial society. Without intense existential environment pressure, people get less religious, and irreligion without definite belief in theism has become more common in the industrious countries such as in the industrious and relatively homogenous European countries without high existential social pressure [60].

Through the Industrial Revolution, mega centralized empire with agricultural-bronze-iron technologies was converted to the transitional social structure with industrial technology. The industrial technology produced global network of the production-marketing-information for industrial technology. The enlarged network led to the industrial technology driven global social structure which is the interdependent global human community. The current global human community is disordered because of the conflicting theisms from top-down imperial theism, consisting of conflicting personal monotheism, impersonal rational theism, and empirical theism. Within personal monotheism, there are conflicting Judaism, Christianity, and Islam. Disordered global human community leads to the Community Theistic Revolution to produce bottom-down 
community theism. Therefore, the social structure enlargement to global human community derived from the Industrial Revolution is pacified by bottom-up community theism to pacify the internal conflict due to conflicting theisms from top-down imperial theism as in the Equation below.

centralized mega empire with agriculture-bronze-iron

$\stackrel{\text { Industrial Revolution }}{\longrightarrow}$ transitional social structure with industrial technology

global infrastructure for the production-market-information of industrial technology

technology driven global human community $\stackrel{\text { conflicting theisms }}{\longrightarrow}$

disordered global human community $\stackrel{\text { Bottom-up Community Theistic Revolution }}{\longrightarrow}$

peaceful global human community with bottom-up community theism

Top-down imperial theism and bottom-up community theism are two different belief systems. In terms of initiation, execution, and direction, top-down imperial theism believes in theistic initiation and top-down revelation-direction. The conflicting top-down revelation-directions from the conflicting theisms in top-down imperial theism become problematic in the interdependent global human community, because top-down revelation-direction cannot be changed, and the conflicting top-down revelation-directions cannot be resolved and pacified. On the contrary, bottom-up community theism believes in theistic initiation and bottom-up effort-direction. (In atheism, initiation is random without any theistic involvement.) To bottom-up community theism without top-down revelation-direction, the conflicting theisms can be resolved and pacified by bottom-up effort-direction to form the global multilateral human community.

The fourth industrial revolution not only individualizes global production-marketing-information but also individualizes virtual reality creating an individualized digital avatar for immortality and the afterlife [61] [62]. The combination of bottom-up community theism and the individualized virtual world produces the additional theistic initiation for the afterlife, where an individual transits smoothly from the biological family-community to the bottom-up familiar virtual family-community instead of top-down strange pre-determined heaven-hell, reincarnation, or impersonal form. Such bottom-up transition to the afterlife is quite popular among people without strong top-down religious doctrines. Even in the Hebrew Bible for Judaism, the death of an individual is to return to the individual's ancestors regardless of the behaviors of the individual. This Jewish belief in the afterlife was shared by the other religions in Canaan [63]. Since everyone has families and communities, the bottom-up familiar virtual family-community in the afterlife can be considered as the common sense afterlife.

In bottom-up community theism, a person's biological life is converted into the person's virtual life in the afterlife with the virtual mental protection system consisting of the virtual social brain and the virtual mental immune system. A virtual mother in the afterlife still concerns about her child on earth, and still wants to be her child's champion and guardian. A virtual mother is happy when her child on earth remembers her. Without the biological desire involving biological human body, the virtual mental protection system is peaceful and coop- 
erative. A person's earthly family-community is converted into the person's virtual family-community in the afterlife. All religious or irreligious communities are just like any other communities. The religious founders in the afterlife still concern about their followers, and still want to be their followers' champions and guardians. Religious founders are happy when their followers on earth remember them. Without the earthly desire involving earthly territory, the virtual global family-community has the common destiny. In other words, there is no outgroup in the virtual global family-community in the afterlife. At the same time, this biological world and the virtual world in the afterlife share the common destiny. Consequently, the present generation in this world is obligated to account for the past generations in the afterlife and the future generations in the future world. We must not let our ancestors down, and must not let our descendants down.

Since individual human effort is important for bottom-up community theism, in terms of the four bases in the theistic gene, bottom-up community theism has strong instinct, strong empiricism, medium theistic imagination, and medium rationalism similar to empirical theism. Society together with family is responsible to nurture the instinctive mental protection system in all people through moral education, mental exercise, mental growth, effort, and observation-experience. Top-down imperial theism can be converted into bottom-up theism through bottom-up effort-direction and afterlife. As a result, bottom-up community theism consists of community personal monotheism (Community Judaism, Community Christianity, and Community Islam), community impersonal rational theism (Community Hinduism, Community Daoism, and Community Greek philosophy), and community empirical theism (Community Buddhism and Community Confucianism). In the transformation from top-down imperial theism to bottom-up community theism, some of the teachings in top-down imperial theism become metaphorical and historical.

\section{Conclusions}

In summary, this paper deals with the evolution of theisms in accordance of a biological understanding of evolution. This paper posits that in the evolution of theisms, the main function of theism is to pacify enlarged social structure derived from technological revolution. As a result, the four technological revolutions (the Upper Paleolithic, Agricultural-Bronze, Iron, and Industrial Revolutions) result in the four theistic revolutions (the Egalitarian Band, Pluralistic State, Top-down Imperial, and Bottom-up Community Theistic Revolutions, respectively for the egalitarian band, pluralistic state, top-down imperial, and bottom-up community theisms, respectively) to pacify the four enlarged social structures (linked egalitarian bands, decentralized union of hierarchical states, mega centralized empire, and global human community, respectively) by pacifying their internal conflicts.

This paper posits that the four mental bases for theistic genes are instinct (the instinctive mental protection system), empiricism (observation-experience), 
theistic imagination (theistic theory of mind), and rationalism (rational system). The mental bases are classified in terms of priority: strong (high priority), medium (middle priority) and weak (low priority). Different theisms have different order of mental bases in terms of priority. The mechanism of evolution is natural selection. For natural selection of the evolution of theisms through individual innovations, theism better adapted to their environment, mainly, the technological revolution, tends to survive and propagate. Theism species follow theistic taxonomy in terms of kingdom, phylum, class, order, family, genus, and species.

Initially, the stable egalitarian band social structure of hunter-gatherers with the small social group size instinct of about 150 people (Dunbar's Number) had irreligious pre-theism without significant religious practices. The social structure enlargement to linked egalitarian bands derived from the Upper Paleolithic Revolution for complex tools was pacified by egalitarian band theism (animism, afterlife, and shamanism) which linked egalitarian bands through theistic imagination to pacify the internal conflict due to the small social group size instinct from pre-theism. The social structure enlargement to decentralized union of hierarchical states derived from the Agricultural-Bronze Revolution was pacified by pluralistic state theism which had hierarchical high deities to pacify the internal conflict due to egalitarianism from egalitarian band theism. The social structure enlargement to mega centralized empire derived from the Iron Revolution was pacified by top-down imperial theism (personal monotheism, impersonal rational theism, and empirical theism) which has top-down mega deity to pacify the internal conflict due to the conflicting deities from pluralistic state theism. The social structure enlargement to global human community derived from the Industrial Revolution is pacified by bottom-up community theism with bottom-up effort-direction and afterlife to pacify the internal conflict due to conflicting theisms from top-down imperial theism. The summary of the evolution of theisms is listed in Table 8.

Table 8. The evolution of theism.

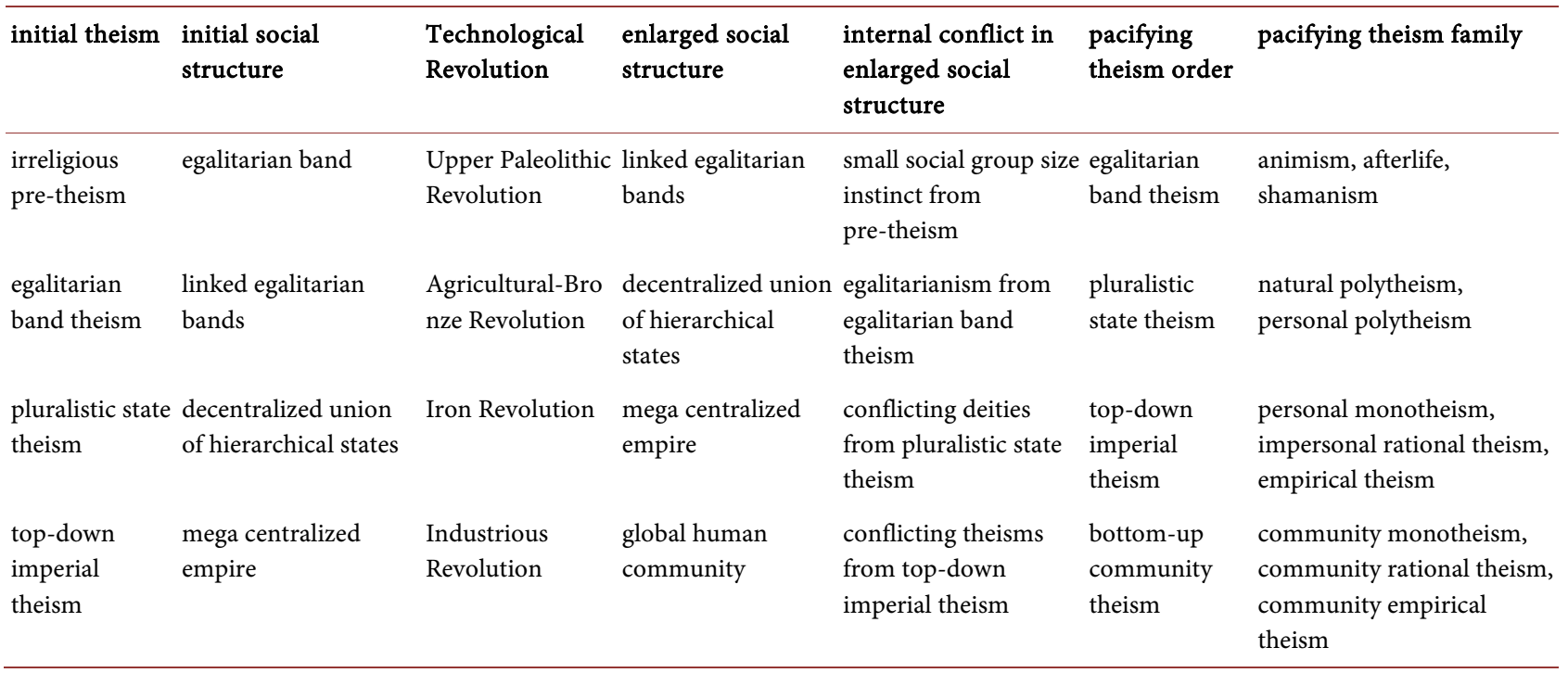


In cosmology, physical elementary particles follow top-down physical laws and conservation laws with the pre-determined cosmological direction. In the evolution of biological species, biological species follow individual organisms' mutations and natural selection with organisms' efforts and without pre-determined evolutionary direction. In the evolution of theisms, theisms follow individual human innovations and natural selection with human effort-direction and without pre-determined evolutionary direction. In top-down imperial theism, the believers believe in top-down revelation-direction and afterlife. In bottom-up community theism, the believers believe in bottom-up effort-direction and afterlife. In conclusion, cosmology and top-down imperial theism are top-down processes, while the evolution of biological species, the evolution of theisms, and bottom-up community theism are bottom-up processes involving bottom-up organisms' efforts.

\section{Conflicts of Interest}

The author declares no conflicts of interest regarding the publication of this paper.

\section{References}

[1] Bellah, R. (2011) Religion in Human Evolution: From the Paleolithic to the Axial Age. Harvard University Press, Cambridge, MA.

https://doi.org/10.4159/harvard.9780674063099

[2] Mayr, E. (1988) Toward a New Philosophy of Biology. Harvard University Press, Cambridge, MA.

[3] Turner, J., Maryanski, A., Klostergaard, A., Petersen, K. and Geertz, A. (2017) The Emergence and Evolution of Religion by Means of Natural Selection. Routledge, New York. https://doi.org/10.4324/9781315111995

[4] Wunn, I. and Grojnowski, D. (2019) Religious Speciation: How Religions Evolve. Springer International Publishing, New York.

[5] Chung, D. (2018) The Mental Protection System for Protective Behaviors: The Social Brain and the Mental Immune System. Journal of Behavioral and Brain Science, 8, 31-55. https://doi.org/10.4236/jbbs.2018.81003

[6] Hamilton, W. (1964) The Genetical Evolution of Social Behavior: II. Journal of Theoretical Biology, 7, 17-52. https://doi.org/10.1016/0022-5193(64)90039-6

[7] Dunbar, R.I.M. (2009) The Social Brain Hypothesis and Its Implications for Social Evolution. Annals of Human Biology, 36, 562-572. https://doi.org/10.1080/03014460902960289

[8] Dunbar, R.I.M. (2016) The Social Brain Hypothesis and Human Evolution. Oxford Research Encyclopedia of Psychology, 1-33. https://doi.org/10.1093/acrefore/9780190236557.013.44

[9] Cozolino, L. (2006) The Neuroscience of Human Relationships: Attachment and the Developing Social Brain. W. W. Norton \& Company, New York.

[10] Wilson, E.O. (2012) The Social Conquest of the Earth. W. W. Norton \& Company, New York.

[11] Chung, D. (2016) The Basic Principles of Kin Sociality and Eusociality: Human Evolution. Natural Science, 8, 8-19. https://doi.org/10.4236/ns.2016.81002 
[12] Erikson, E. and Erikson, J. (1998) The Life Cycle Completed. W. W. Norton \& Company, New York.

[13] Slater, C.L. (2003) Generativity versus Stagnation: An Elaboration of Erikson's Adult Stage of Human Development. Journal of Adult Development, 10, 53-65. https://doi.org/10.1023/A:1020790820868

[14] McAdams, D. and De St. Aubin, E. (1992) A Theory of Generativity and Its Assessment through Self-Report, Behavioral Acts, and Narrative Themes in Autobiography. Journal of Personality and Social Psychology, 62, 1003-1015. https://doi.org/10.1037/0022-3514.62.6.1003

[15] Chung, D.Y. (2018) The Eight Stages of Psychosocial Protective Development: Developmental Psychology. Journal of Behavioral and Brain Science, 8, 369-398. https://doi.org/10.4236/jbbs.2018.86024

[16] Turner, J.C. and Reynolds, K.J. (2010) The Story of Social Identity. In: Postmes, T. and Branscombe, N., Eds., Rediscovering Social Identity: Core Sources, Psychology Press, New York, 13-32.

[17] Cohen, T., Montoya, R. and Insko, C. (2006) Group Morality and Intergroup Relations: Cross-Cultural and Experimental Evidence. Personality and Social Psychology Bulletin, 32, 1559-1572. https://doi.org/10.1177/0146167206291673

[18] Hamlin, J., Mahajan, N. and Wynn, K. (2013) Not Like Me = Bad Infants Prefer Those Who Harm Dissimilar Others. Psychological Science, 24, 589-594. https://doi.org/10.1177/0956797612457785

[19] Kapogiannis, D., Deshpande, G., Krueger, F., Thornburg, M.P. and Grafman, H.J. (2014) Brain Networks Shaping Religious Belief. Brain Connectivity, 4, 70-79. https://doi.org/10.1089/brain.2013.0172

[20] Norenzayan, A., Gervais, W. and Trzesniewski, K. (2012) Mentalizing Deficits Constrain Belief in a Personal God. PLoS ONE, 7, e36880. https://doi.org/10.1371/journal.pone.0036880

[21] Kapogiannis, D., et al. (2009) Cognitive and Neural Foundations of Religious Belief. Proceedings of the National Academy of Sciences, 106, 4876-4881. https://doi.org/10.1073/pnas.0811717106

[22] Heyes, C. (2015) Animal Mindreading: What's The Problem? Psychonomic Bulletin \& Review, 22, 313-327. https://doi.org/10.3758/s13423-014-0704-4

[23] Bloch, M. (2006) Why Religion Is Nothing Special but Is Central. Philosophical Transactions of the Royal Society B, 363, 2055-2061. https://doi.org/10.1098/rstb.2008.0007

[24] Chung, D. (2016) The Human Religious Evolution. Open Journal of Social Sciences 4, 75-90.

[25] Tang, Y., Hölzel, B. and Posner, M. (2015) The Neuroscience of Mindfulness Meditation. Nature Reviews Neuroscience, 16, 213-225. https://doi.org/10.1038/nrn3916

[26] Norenzayan, A., et al. (2016) The Cultural Evolution of Prosocial Religions. Behavioral and Brain Sciences, 39, e1. https://doi.org/10.1017/S0140525X14001356

[27] Shilling, C. and Mellor, P. (1998) Durkheim, Morality and Modernity: Collective Effervescence, Homo Duplex and the Sources of Moral Action. The British Journal of Sociology, 49, 193-209.

[28] Zatrev, J. (2014) The Co-Evolation of Human Intersubjectivity, Morality, and Language. In: Daniel, D., Chris, K. and Jerome, L., Eds., The Social Origins of Language, Oxford University Press, Oxford, 249-266.

[29] Hill, K. (2011) Co-Residence Patterns in Hunter-Gatherer Societies Show Unique 
Human Social Structure. Science, 331, 1286-1289.

[30] Dunbar, R. (1993) Coevolution of Neocortex Size, Group Size and Language in Humans. Behavioral and Brain Sciences, 16, 681-735. https://doi.org/10.1017/S0140525X00032325

[31] Wunn, I. (2000) Beginning of Religion. Numen, 47, 417-453. https://doi.org/10.1163/156852700511612

[32] Sahlins, M. (1968) Notes on the Original Affluent Society. In: Lee, R. and DeVore, I. Eds., Man the Hunter, Aldine de Gruyter, New York, 85-89.

[33] Bar-Yosef, O. (2002) The Upper Paleolithic Revolution. Annual Review of Anthropology, 31, 363-393. https://doi.org/10.1146/annurev.anthro.31.040402.085416

[34] Dixson, A. and Dixson, B. (2011) Venus Figurines of the European Paleolithic: Symbols of Fertility or Attractiveness? Journal of Anthropology, 2011, Article ID: 569120. https://doi.org/10.1155/2011/569120

[35] Lewis-Williams, D. (2002) The Mind in the Cave: Consciousness and the Origins of Art. Thames \& Hudson, London.

[36] Cunliffe, B. (2001) The Oxford Illustrated History of Prehistoric Europe. Oxford University Press, Oxford.

[37] Peoples, H., Duda, P. and Marlowe, F. (2016) Hunter-Gatherers and the Origins of Religion. Human Nature, 27, 261-282. https://doi.org/10.1007/s12110-016-9260-0

[38] Stringer, M. (1999) Rethinking Animism: Thoughts from the Infancy of Our Discipline. Journal of the Royal Anthropological Institute, 5, 541-556. https://doi.org/10.2307/2661147

[39] Graham, H. (2006) Animism: Respecting the Living World. Columbia University Press, New York.

[40] Hoppál, M. (1987) Shamanism: An Archaic and/or Recent System of Beliefs. Theosophical Publishing House, Wheaton, IL.

[41] Winkelman, M. (1990) Shamans and Other Magico-Religious Healers: A Cross-Cultural Study of Their Origins, Nature, and Social Transformations. Ethos, 18, 308-352. https://doi.org/10.1525/eth.1990.18.3.02a00040

[42] Steadman, L., Palmer, C. and Tilley, C. (1996) The Universality of Ancestor Worship. Ethnology, 35, 63-76. https://doi.org/10.2307/3774025

[43] Swanson, G. (1960) The Birth of the Gods: The Origin of Primitive Belief. University of Michigan Press, Ann Arbor, MI. https://doi.org/10.3998/mpub.6484

[44] Davies, P. (2010) Urban Religion and Rural Religion. In: Stavrakopoulou, F. and Barton, J., Eds., Religious Diversity in Ancient Israel and Judah, Continuum International Publishing Group, New York.

[45] Stern, E. (2001) Archaeology of the Land of the Bible, Volume II, The Assvrian. Doubleday \& McClure Company, New York.

[46] Smith, M. (2001) Untold Stories: The Bible and Ugaritic Studies in the Twentieth Century. Hendrickson Publishers, Peabody, MA.

[47] Bosworth, A. (1995) World Cities and World Economic Cycles. In: Sanderson, S.K., Ed., Civilizations and World Systems, Alta Mira Press, Walnut Creek, CA, 206-228.

[48] Muhly, J. (2003) Metalworking/Mining in the Levant. In: Richard, S., Ed., Near Eastern Archaeology, Eisenbrauns, Winona Lake, IN.

[49] Nikiprowetzky, V. (1975) Ethical Monotheism, Daedalus, 104, 80-81.

[50] Whitmarsh, T. (2015) Battling the Gods: Atheism in the Ancient World. Alfred A. Knopf Inc., New York. 
[51] Ramakrishna, P. (1997) Fundamentals of Indian Philosophy. D. K. Printworld Ltd., New Delhi, India.

[52] Komjathy, L. (2014) Daoism: A Guide for the Perplexed. Bloomsbury Academic, New York

[53] Jaspers, K. (1953) The Origin and Goal of History. Yale University Press, New Haven.

[54] Flood, G. (1996) An Introduction to Hinduism. Cambridge University Press, Cambridge, England.

[55] Laumakis, S. (2008) An Introduction to Buddhist Philosophy. Cambridge University Press, Cambridge. https://doi.org/10.1017/CBO9780511800818

[56] Tang, Y., Hölzel, B. and Posner, M. (2015) The Neuroscience of Mindfulness Meditation. Nature Reviews Neuroscience, 16, 213-225. https://doi.org/10.1038/nrn3916

[57] Goldin, P. (2011) Confucianism. University of California Press, Oakland, CA.

[58] Byrne, P. (2013) Natural Religion and the Nature of Religion: Legacy of Deism. Routledge, New York. https://doi.org/10.4324/9780203533093

[59] Schwab, K. (2017) The Fourth Industrial Revolution. Crown Publishing Group, New York.

[60] Pew Research Center (2012) Religiously Unaffiliated. Pew Research Center, Washington DC.

http://www.pewforum.org/2012/12/18/global-religious-landscape-unaffiliated/

[61] Graziano, M. (2016) Why You Should Believe in the Digital Afterlife. The Atlantic, Boston, MA.

https://www.theatlantic.com/science/archive/2016/07/what-a-digital-afterlife-would -be-like/491105/

[62] Jacobsen, M. (2017) Postmortal Society: Towards a Sociology of Immortality. Routledge, New York. https://doi.org/10.4324/9781315601700

[63] Segal, A. (2010) Life after Death: A History of the Afterlife in the Religions of the West. Crown Publishing Group, Danvers, MA. 